\title{
Deep-sea shrimps of the family Aristeidae (Decapoda: Dendrobranchiata) from northern Japan, with the description of a new species of the genus Aristeus
}

\section{Tomoyuki Komai}

Abstract. - Five species belonging to the family Aristeidae are reported from the Pacific coast of northern Japan. One, Aristeus pallidicauda, is described as new based on a male and female specimens from off Miyako, Iwate Prefecture, at depths of 500-700 m. Plesiopenaeus edwardsianus (Johnson, 1867) is reported from northern Japan for the first time. Three species previously recorded from this area also included, Aristaeomorpha foliacea (Risso, 1827), Aristeus virilis (Bate, 1881), and Aristeus mabahissae Ramadan, 1938. The present material represents the northern limit of the distribution of these species in the western Pacific.

During a survey of the deep-sea crustacean fauna along the poorly explored Pacific coast of northeastern Honshu mainland, Japan, a small collection of aristeid shrimps was obtained. It includes five species, Aristaeomorpha foliacea (Risso, 1827), Aristeus mabahissae Ramadan, 1938, A. pallidicauda, new species, $A$. virilis (Bate, 1881), and Plesiopenaeus edwardsianus (Johnson, 1867). Among the eight recognized species of Aristeus, the new species appears to be allied to Aristeus antennatus (Risso, 1816) and A. antillensis A. Milne Edwards \& Bouvier, 1909, but can be distinguished from them by the relative lengths of some pereopodal articles, the number of pereopodal photophores, and morphology of the male third maxilliped and female episternite on the eighth thoracic somite.

The specimens examined are deposited in the Laboratory of Marine Zoology, Faculty of Fisheries, Hokkaido University (HUMZ). Most of the terminology used in the description is that proposed and illustrated by Pérez Farfante (1977). The structure on the eighth thoracic sternite situated posterior to the coxae of the fifth pereopods is termed as "episternite" following Crosnier \& Forest (1973). The following abbreviations are used in the text: $\mathrm{CL}=$ postorbital carapace length; $\mathrm{MNHN}=$ Muséum national d'Histoire naturelle; NSMT = National Science Museum, Tokyo. Color is described on the basis of fresh or live specimens.

\section{Systematics}

Family Aristeidae

Genus Aristaeomorpha Wood-Mason, 1891 Aristaeomorpha foliacea (Risso, 1827)

Restricted synonymy:

Penaeus foliaceus Risso, 1827: 69, pl. 2, fig. 6.

Aristaeomorpha foliacea: Kubo, 1949: 200, figs. 1A, 8Z, 14E, 19B, 23C, D, 36E, F, 44A-C, 65C, D, 72A, G, 78F, 87-89; 1965: 596, fig. 897. - Crosnier, 1978: 54, figs. 23, 24. - Miyake, 1982: 1, pl. 1, fig. 1. - Hayashi, 1983b: 281, figs. 53, 54a-e, 56a-f; 1986: 50 (fig. 11), 51, 236. - Pérez Farfante, 1988: 6, fig. 6. - Hayashi, 1992: 22 , figs. $8,14,15$.

Material examined. - HUMZ-C 4, 2 females (CL $42.8 \mathrm{~mm}$ and $54.5 \mathrm{~mm}$ ), off Miyako, Iwate Prefecture, 500-600 m, Mar. 
Table 1. Aristeus mabahissae Ramadan, 1938. Comparison of the chela-propodus length ratios in the first to third pereopods, carpus-merus ratios in the fourth and fifth pereopods, and numbers of pereopodal photophores in the specimens examined and the Madagascar specimens reported by Crosnier (1978: 63, 64). (Average and number of the specimens examined are given in parentheses for the proportional characters; abbreviations are as follows: $\mathrm{C}=$ carpus, $\mathrm{D}=$ dactylus, $\mathrm{P}=$ propodus, $\mathrm{Per}=$ pereopod ).

\begin{tabular}{lll}
\hline \hline & Specimens examined & Madagascar specimens \\
\hline Chela/Carpus & & \\
1 Per & $1.03-1.28(1.13, \mathrm{~N}=4)$ & $1.07-1.25(1.07, \mathrm{~N}=12)$ \\
2 Per & $0.93-1.01(0.97, \mathrm{~N}=3)$ & $0.76-1.00(0.95, \mathrm{~N}=12)$ \\
3 Per & $0.78-0.85(0.82, \mathrm{~N}=4)$ & $0.71-0.79(0.75, \mathrm{~N}=12)$ \\
& & \\
Carpus/Merus & $0.94-1.00(0.98, \mathrm{~N}=4)$ & $0.88-0.98(0.92, \mathrm{~N}=11)$ \\
4 Per & $1.11-1.18(1.15, \mathrm{~N}=2)$ & $0.98-1.06(1.01, \mathrm{~N}=11)$ \\
5 Per & & \\
& & $\mathrm{C} 6-9, \mathrm{P} 0-2$ \\
No. of Photophores & $\mathrm{C} 2-8, \mathrm{P} 1-2$ & $\mathrm{C} 2-4, \mathrm{P} 0-2$ \\
1 Per & $\mathrm{C} 1-6, \mathrm{P} 1$ & $\mathrm{C} 0-5, \mathrm{P} 0-2$ \\
2 Per & $\mathrm{C} 1-6, \mathrm{P} 0-3$ & $\mathrm{C} 4-8, \mathrm{P} 8-11, \mathrm{D} 4-5$ \\
3 Per & $\mathrm{C} 8-9, \mathrm{P} 8-10$ & \\
4 Per & $\mathrm{C} 9-10, \mathrm{P} 11, \mathrm{D} 5-7$ & \\
5 Per & & \\
\hline
\end{tabular}

1985, Danish seine. HUMZ-C 1571, 1 male (CL $37.6 \mathrm{~mm}$ ), off Sohma, Fukushima Prefecture, $37^{\circ} 54^{\prime} \mathrm{N}, 141^{\circ} 54^{\prime} \mathrm{E}, 400 \mathrm{~m}, 17$ May 1990, otter trawl (R/V Tanshu-Maru).

Coloration. - Body red, darker in branchial and oral regions, with distinct small red patches or spots on ventral surface, scaphocerites, and uropods.

Distribution. - Widely distributed in warm temperate and tropical region of the world oceans, at depths of 61-1300 m. This species has been recorded in Japanese waters from Sagami Bay to East China Sea (Hayashi, 1983b). Toriyama (1986) listed this species from the Pacific area off the northeastern coast of Honshu mainland.

Genus Aristeus Duvernoy, 1840 Aristeus mabahissae Ramadan, 1938

Restricted synonymy:

Aristeus mabahissae Ramadan, 1938: 43, figs. 2b, 3b, 4a-c. - Crosnier, 1978: 65, figs. 25a-c, 26c-f. - Hayashi, 1983a: 190, figs. 49, 50a-e, 52a, b. - Crosnier, 1984:
22. - Hayashi, 1986: 52 (fig. 12), 53, 227; 1992: 18, figs. 9, 11, 13a, b. - Komai, 1991: 60 .

Material examined. - HUMZ-C 3, 1 female (CL $38.7 \mathrm{~mm}$ ), off Miyako, 500-600 m, 28 Dec. 1985, Danish seine. HUMZ-C 921, 1 female (CL $38.0 \mathrm{~mm}$ ), off Hachinohe, Aomori Prefecture, $40^{\circ} 32^{\prime} \mathrm{N}, 144^{\circ} 12^{\prime} \mathrm{E}, 639$ m, 2 April 1989, otter trawl (T/S HokuseiMaru). HUMZ-C 1572, 1 male $(26.8 \mathrm{~mm}$ CL), off Miyako, 500-600 m, 26 Dec. 1985, Danish seine. HUMZ-C 1573, 1 male (CL $31.0 \mathrm{~mm}$ ), off Miyako, 500-600 m, 9 Jan. 1986, Danish seine.

Distribution. - The previous records suggest that $A$. mabahissae is widely distributed in the tropical and subtropical regions of the Indo-West Pacific, at depths of 366-1097 $\mathrm{m}$. In Japanese waters, it has been recorded from the Kyushu Palau Ridge, East China Sea (Hayashi, 1983a; 1986), and off Daikoku-jima, eastern Hokkaido (Komai, 1991).

Remarks. - Crosnier (1978) presented 
two tables in which characters of four species of Aristeus from Madagascar, Indian Ocean, were compared. The ratios of chela to carpus in the first to third pereopods and those of carpus to merus in the fourth and fifth pereopods, and the number of the pereopodal photophores of $A$. mabahissae reported by Crosnier (1978) from Madagascar, are compared with those of the present material (Table 1). It has been found that the ratios of chela to carpus of the third pereopod and that of carpus to merus of the fifth pereopod are slightly greater than those reported by Crosnier. On the other hand, the numbers of the pereopodal photophores are well within the range given by Crosnier. This suggests that the geographical intraspecific variations of this species are small. The remaining diagnostic features given by Crosnier (1978) agree with those in the present material.

The specimens of A. mabahissae from northern Japan show distinct sexual dimorphism in the relative length of the scaphocerite. The scaphocerites in the males are relatively longer than in the females (0.90-0.91 times as long as carapace vs. 0.74 -0.78 times as long). It is uncertain at present that the relative length of the scaphocerite varies sexually in other species of Aristeus. Regarding the other aristeid genera, similar sexual dimorphism is known in the genus Pseudaristeus (Pérez Farfante, 1987).

\section{Aristeus pallidicauda new species} Figs. 1-4

Material examined. - Holotype: HUMZ-C 206, male (CL $24.7 \mathrm{~mm}$ ), off Miyako, 600-700 m, 5 Apr. 1985, Danish seine. Paratype: HUMZ-C 191: 1 female (CL $30.0 \mathrm{~mm}$ ), off Miyako, 500-600 m, 20 Mar. 1986, Danish seine.

Diagnosis. - Body glabrous. Carapace with branchiostegal carina falling slightly short of level of anterior extremity of cervical carina. Propodus of third maxilliped with dorsodistal margin distinctly produced forward. Chelae distinctly longer than carpi in first and second pereopods, subequal to in third pereopod. Second and third pereopods without photophore on carpus; fourth and fifth pereopods with 33-39 photophores on carpus. Pleurobranchs on third to seventh thoracic somites rudimentary, with distinct pinnules. Thelycum with median plate of seventh thoracic somite triangular; episternite appearing as narrow ridge.

Description of male holotype. - Body (Fig. 1) moderately slender, integument thin, without tomentum.

Rostrum (Fig. 1) long (apex broken), more than 0.9 times as long as carapace, overreaching anterior margin of scaphocerite, slightly upturned; dorsal margin armed basally with 3 spines including epigastric spine; ventral margin unarmed; adrostral carina extending from slightly anterior to anterior rostral spine to slightly posterior to level of epigastric spine. Carapace (Figs. 1, 2A) with postrostral carina extending to posterior $1 / 4$ of carapace, its posterior part gradually disappearing; cervical carina blunt, oblique, falling far short of median line; branchiocardiac carina weak, accompanied by shallow sulcus; antennal spine slightly ascending; branchiostegal carina extending approximately to level of anterior extremity of cervical carina; hepatic sulcus shallow; dorsal submarginal carina parallel to carapace margin; ventral submarginal carina extending to posterolateral end of carapace, delimiting ventral membrane.

Abdomen (Fig. 1) with first to third somites rounded dorsally; fourth somite sharply carinate medially in posterior $3 / 4$, fifth and sixth somites sharply carinated medially over entire length; posterodorsal margin of third somite damaged, thus presence or absence of median spine unknown; fourth to sixth somites armed with posteromedian spine. Sixth somite strongly com- 


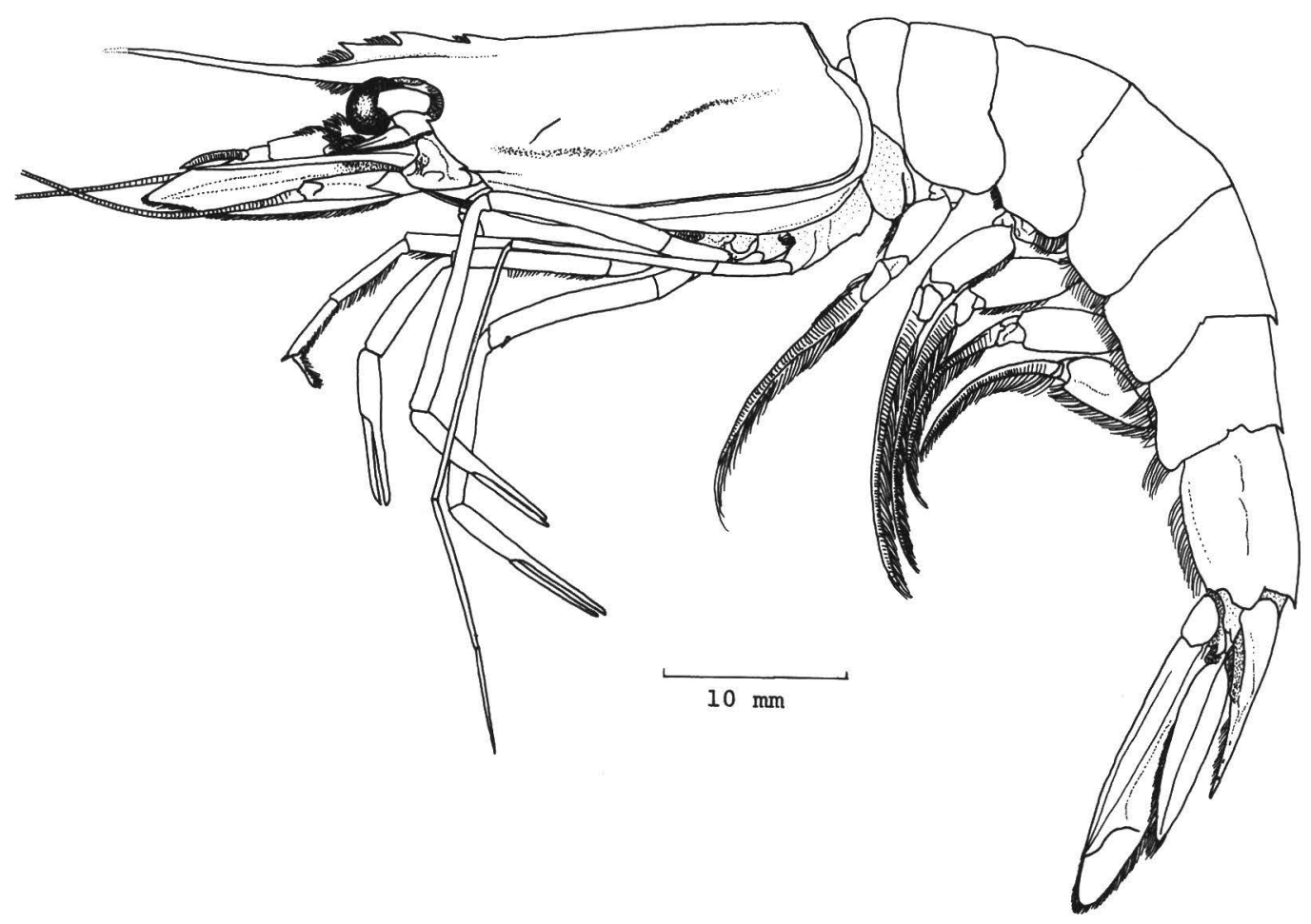

Fig. 1. Aristeus pallidicauda new species, holotype male (CL $24.7 \mathrm{~mm})$, lateral view.

pressed laterally, 0.48 times as long as carapace and 1.6 times as long as anterior depth, armed with minute posteroventral spine and bearing 2 elongate, rather obscure cicatrices laterally. Telson (Fig. 2B) 0.58 times as long as carapace, tapering to acute tip, with moderately deep median sulcus extending along 3/4 length of telson, and flanked by dorsolateral ridges; lateral surface with 2 weak expansions along anterior $2 / 5$ length of telson, and 4 pairs of small spines close to ventral margin, anteriormost pair situated at about posterior $2 / 5$ length of telson and posteriormost pair flanking terminal part.

Eye (Fig. 2C) reaching level of apex of anteriormost rostral spine, with cornea strongly dilated, delimited posteromedially by deep groove; mesial tubercle strong, situated just posterior to base of cornea.

Antennule (Figs. 2D, E) with peduncle reaching distal $1 / 3$ of scaphocerite; proximal article with distolateral margin produced into acute spine; stylocerite (Fig. $2 \mathrm{E}$ ) acute, strongly appressed to proximal article, falling somewhat short of distolateral spine of article, with large proximolateral process directed forward and sharply pointed; prosartema rudimentary, appearing as tubercle with tuft of long setae; intermediate article distinctly shorter than proximal article; distal article much shorter than intermediate article, with circular depression just distal to insertion of outer flagellum. Outer flagellum very short, flattered, reaching only level of distolateral spine of scaphocerite, inserted in central part of dorsolateral face of distal article; inner flagellum long, inserted on tip of distal article, not markedly sinuous proximally.

Scaphocerite (Fig. 2F) 0.76 times as long as carapace, mesial and anterior part membranous, former part folded ventrally; lateral rib broad, accompanied by deep groove mesially, tapering to distal spine falling far short of triangular distal margin of blade. 


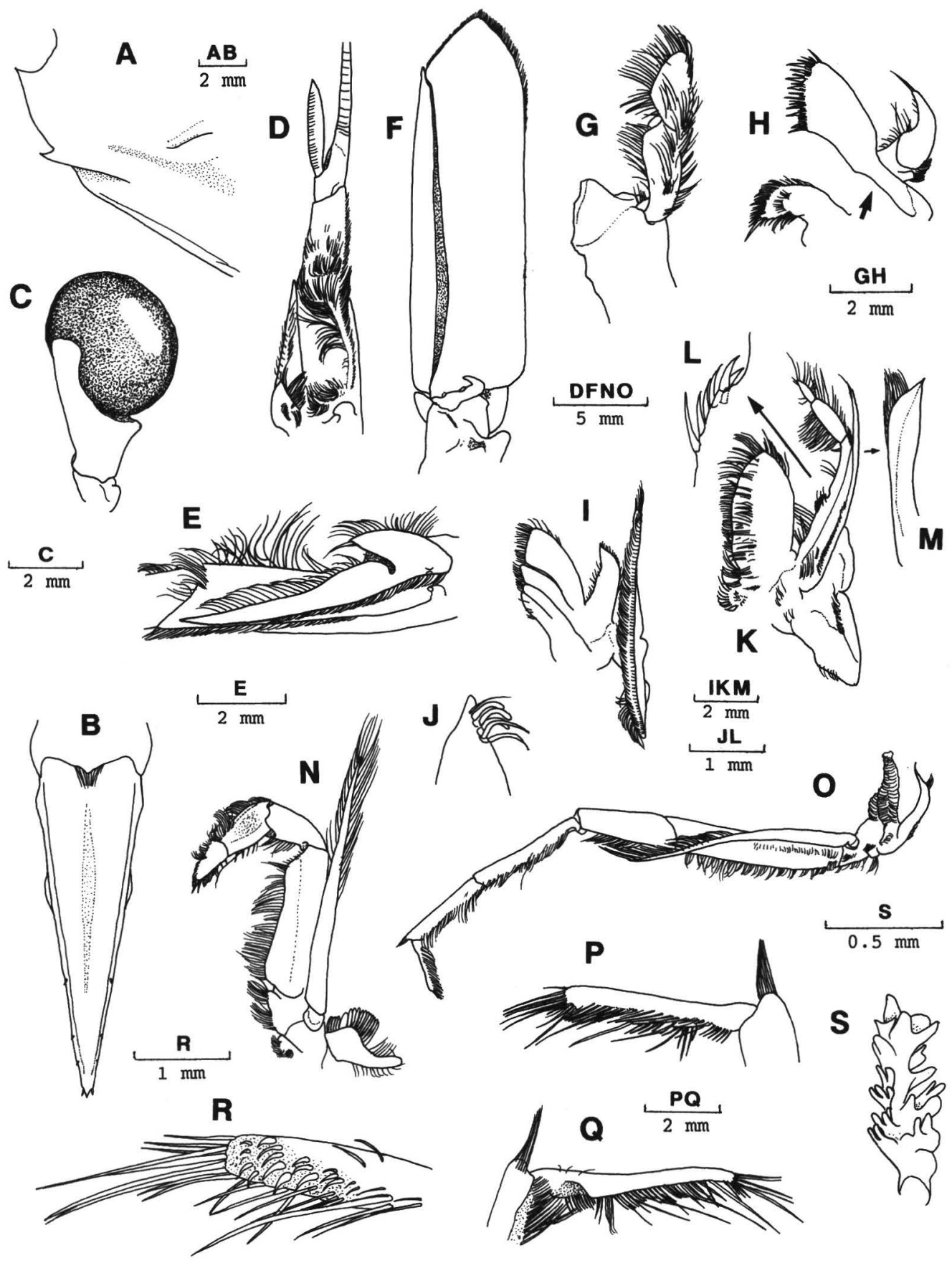

Fig. 2. Aristeus pallidicauda new species, holotype male (CL $24.7 \mathrm{~mm}$ ), body parts and various appendages (dissected from left side). A, anterolateral part of carapace; B, telson, dorsal view; C, eye, dorsal view; D, antennule, dorsal view; E, same, stylocerite and proximal article of peduncle, lateral view; F, antenna, dorsal view; G, mandible; H, maxillule; I, maxilla; J, same, palp, distal portion; K, first maxilliped; L, same, palp, central part of mesial margin; M, same, exopod, lateral view; N, second maxilliped; O, third maxilliped; P, same, dactylus and distal portion of propodus, lateral view; $\mathrm{Q}$, same, mesial view; R, same, distal part of dactylus, lateral view; S, left pleurobranch of seventh thoracic somite. 
Basicerite with dorsal process strongly curved outward, and broadly rounded distolateral process. Carpocerite not reaching midlength of scaphocerite.

Mandible (Fig. 2G) stout, with biarticulated palp overreaching base of ischiocerite of antenna, distal article moderately expanded, with mesial margin strongly convex. Molar process heavy, mesial surface divided into two unequally elevated parts.

Maxillule (Fig. 2H) with palp strongly curved mesially, distal part flattened, distal margin truncate from lateral view, with 4 stout setae. Distal endite diverging mesially, with thick assemblage of various length of spines on mesial margin. Proximal endite broad, thickly setose.

Maxilla (Fig. 2I) with palp broad and flat, not articulated, tapering to acute tip, with row of curved spines on distolateral margin (Fig. 2J). Distal and proximal endites divided into 2 lobes by deep slit respectively. Scaphognathite vertical, with posterior lobe short and rounded posteriorly.

First maxilliped (Fig. 2K) with 4-articulated palp, articulation between first and second articles partly fused; first article armed with 6 spines on distomesial margin (Fig. 2L). Distal endite large, ovate, mesial half of ventral surface obscured by setae. Proximal endite short, concealed by thick setae. Exopod (Fig. 2M) flattened; ventrodistal margin strongly convex, with setae; apex acute. Epipod bilobed, proximal lobule much larger than distal one. Rudimentary arthrobranch present.

Second maxilliped (Fig. 2N) with endopod 7-articulated; merus longer than distal 3 articles combined, with moderately broad mesial expansion; propodus depressed on ventral surface, with tuft of setae on extensor surface near distal margin, flexor margin with row of spines increasing in size distally, apex with 2 strong spines. Exopod subflagelliform, overreaching distal margin of merus by length of distal $1 / 3$. Epipod moderately large, setose, with welldeveloped podobranch. One rudimentary and one well-developed arthrobranchs present.

Third maxilliped (Figs. 1, 2O) with endopod reaching distal $1 / 4$ of scaphocerite, ventral or flexor margin setose; merus 0.6 times as long as ischium measured along ventral margin; propodus 0.8 times as long as carpus, dorsodistal margin produced forward, fringed with setae (Figs. 2P, Q); dactylus (Figs. 2P-R) 0.6 times as long as propodus, somewhat flattened dorsoventrally, with weak expansion on ventromesial margin near base; lateral face with 4 oblique rows of curved spines in distal part. Exopod flagelliform, reaching about middle of merus. Epipod elongate, abruptly tapering distally, with well-developed podobranch. Two well-developed arthrobranch present; pleurobranch rudimentary, but with distinct pinnules.

Anterior 3 pairs of pereopods (Figs. 1, $3 \mathrm{~A}-\mathrm{C})$ with meri compressed laterally, bearing ventrolateral subdistal spine in first and second pereopods; fingers of chelae slender, cutting edges minutely pectinated and bearing tufts of rigid setae. First pereopod (Fig. $3 \mathrm{~A}$ ) reaching level of distolateral spine of scaphocerite; carpus 0.75 times as long as merus, with 13 photophores over entire length of flexor margin; chela 1.62 times as long as carpus, with 5 photophores arranged in 2 rows $(2+3)$ on flexor surface of palm; dactylus 0.83 times as long as palm. Second pereopod (Fig. 3B) overreaching scaphocerite by length of distal 1/4 of chela; carpus 0.99 times as long as merus, without photophore; chela 1.20 times as long as carpus, with 3 photophores arranged in 2 rows $(1+$ 2 ); dactylus 1.32 times as long as palm. Third pereopod (Fig. 3C) overreaching scaphocerite by length of distal $1 / 3$ of chela; carpus 1.19 times as long as merus, without photophore; chela 0.94 times as long as carpus, with 2 photophores; dactylus 1.28 times as long as palm. Fourth pereopod (Fig. 3D) (left missing) very long and thin, overreaching scaphocerite by length of distal 1/4 of dactylus; merus with short setae 


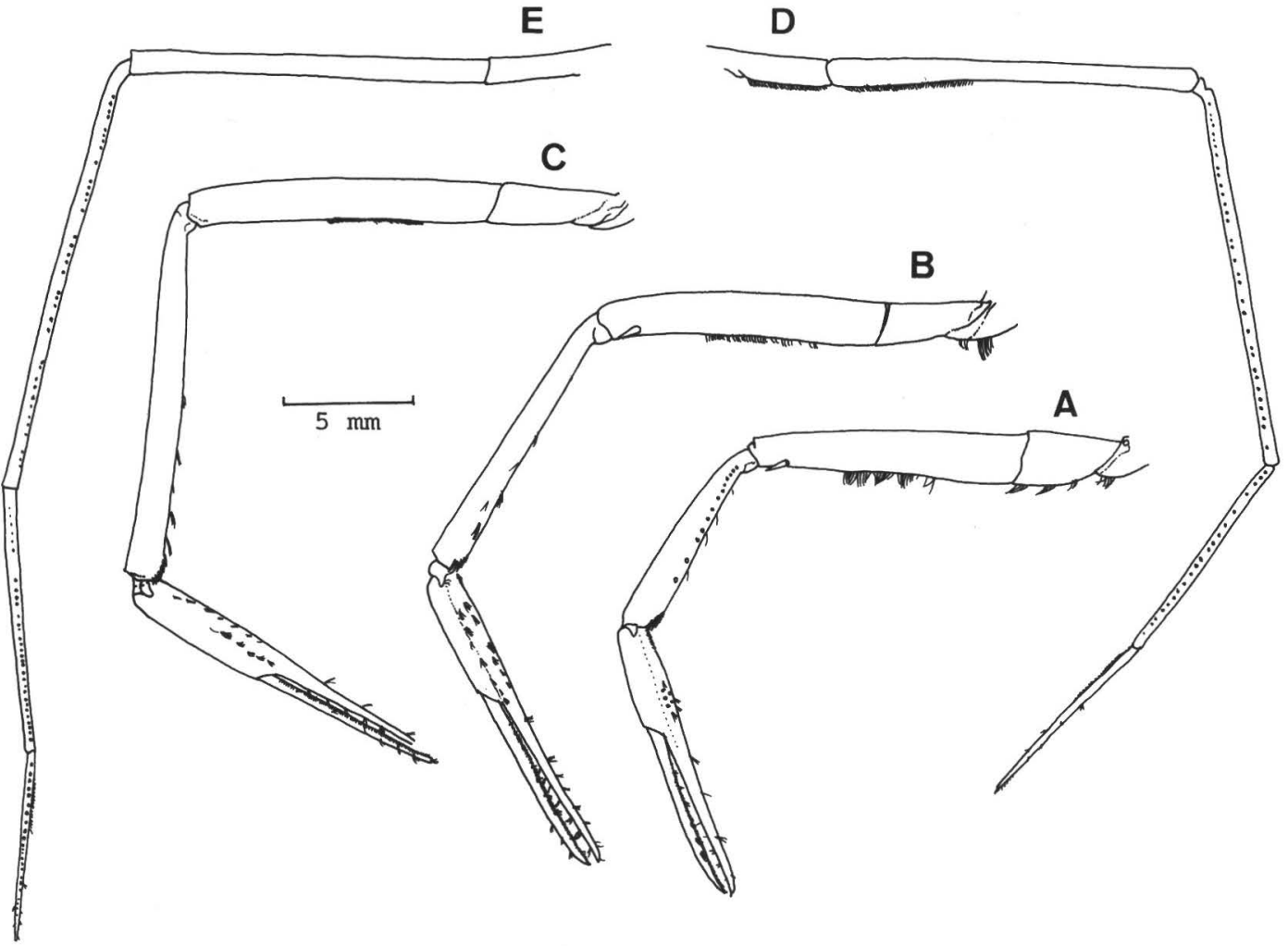

Fig. 3. Aristeus pallidicauda new species, holotype male (CL $24.7 \mathrm{~mm}$ ). Left pereopods (except D, right). A, first pereopod; B, second pereopod; C, third pereopod; D, fourth pereopod; E, fifth pereopod.

along proximal $2 / 5$ of ventral margin; carpus 1.02 times as long as merus, with 33 photophores over entire length; propodus 0.59 times as long as carpus, with 20 photophores over entire length; dactylus 0.88 times as long as propodus, with scattered tufts of rigid setae. Fifth pereopod (Fig. $3 \mathrm{E})$ somewhat longer than fourth pereopod, overreaching scaphocerite by length of dactylus and distal $1 / 3$ of propodus; merus without ventral setae; carpus 1.22 times as long as merus, with 36 photophores; propodus 0.59 times as long as carpus, with 31 photophores; dactylus 0.71 times as long as propodus, with 22 photophores over entire length, tufts of setae fewer than in fourth pereopod.

Branchial formula as follows (r: rudimentary):

Exopods absent from pereopods.

\begin{tabular}{|c|c|c|c|c|c|c|c|c|}
\hline & \multicolumn{3}{|c|}{ Maxillipeds } & \multicolumn{5}{|c|}{ Pereopods } \\
\hline & 1 & 2 & 3 & 1 & 2 & 3 & 4 & 5 \\
\hline Pleurobranch & - & - & $\mathrm{r}$ & $r$ & $r$ & $\mathrm{r}$ & $\mathrm{r}$ & 1 \\
\hline Arthrobranch & $\mathrm{r}$ & $\mathrm{r}+1$ & 2 & 2 & 2 & 2 & 2 & - \\
\hline Podobranch & 1 & 1 & 1 & 1 & 1 & 1 & - & - \\
\hline Epipod & 1 & 1 & 1 & 1 & 1 & 1 & - & - \\
\hline Exopod & 1 & 1 & 1 & - & - & - & - & - \\
\hline
\end{tabular}

Epipods on anterior 3 pairs of pereopods large, non-bifurcate, deeply inserted into branchial chamber, with podobranch. Two arthrobranchs on each of first to fourth pereopods, all but one well developed; anterior member on fourth pereopod rudimentary. Pleurobranchs on fourth to seventh thoracic somites (Fig. 2S) rudimentary, but with distinct pinnules, that on eighth somite well developed. 

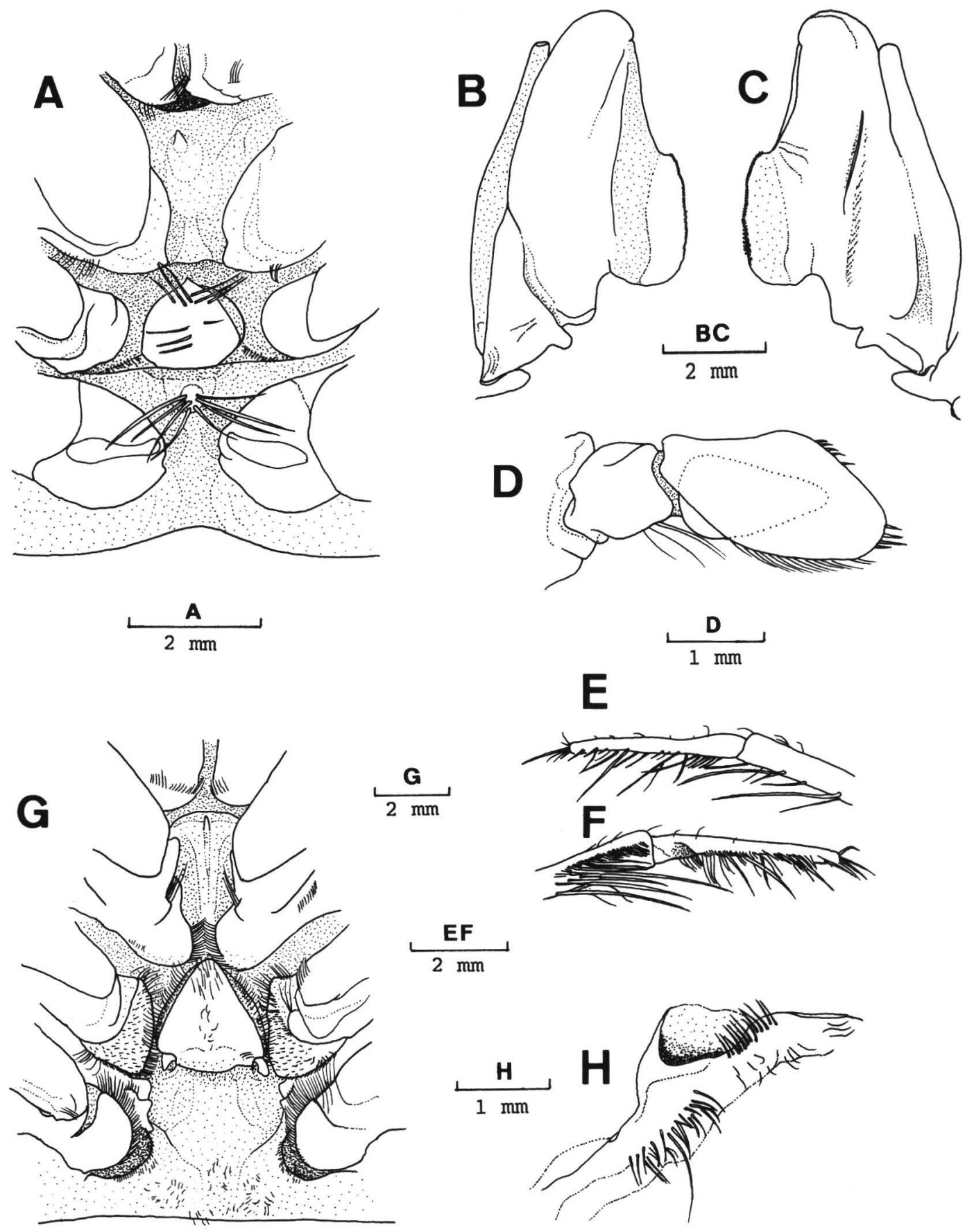

Fig. 4. Aristeus pallidicauda new species, holotype male $(24.7 \mathrm{~mm})$ (A-D), and paratype female (CL 30. $0 \mathrm{~mm})(\mathrm{E}-\mathrm{H})$. A, sixth to eighth thoracic sternites, ventral view; B, left petasma, dorsal view; C, same, ventral view; D, left appendix masculina and interna, mesial view; E, distal part of left third maxilliped, lateral view; F, same, mesial view; $G$, thelycum, ventral view; $H$, left episternite, ventral view. 


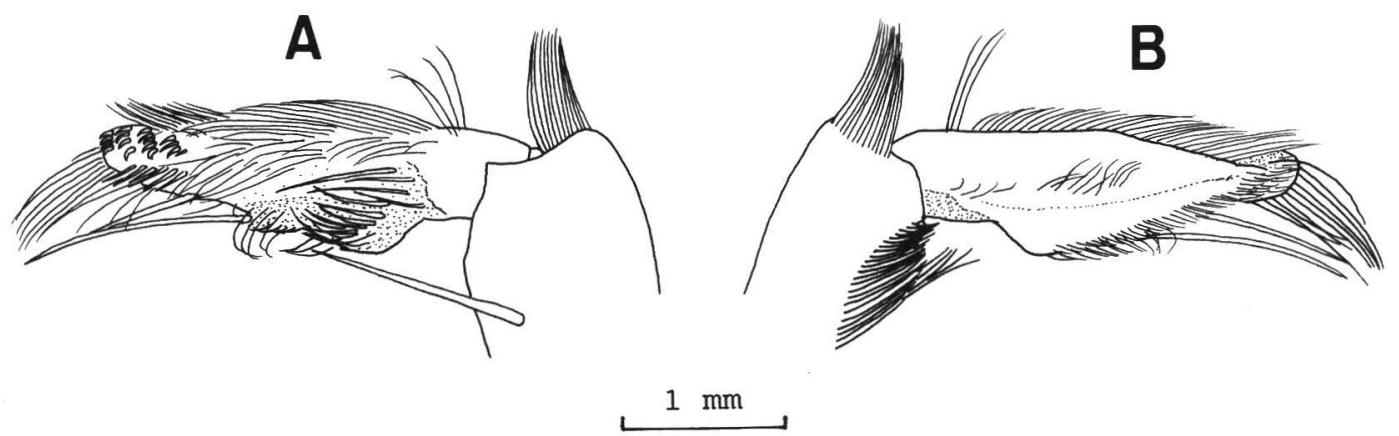

Fig. 5. Aristeus antennatus (Risso, 1816), male (MNHN Na 38: CL $26.5 \mathrm{~mm}$ ). A, distal part of left third maxilliped, lateral view; B, same, mesial view.

First and second pleopods with exopod distinctly shorter than carapace.

Petasma (Figs. 4B, C) with median lobules not strongly folded. Dorsomedian lobule about $1 / 3$ length of petasma, cincinnulate over entire mesial margin. Ventrodistal lobule falling distally short of dorsolateral lobule and bearing elongate, lapel-like flap distoventrally along mesial margin. Dorsolateral lobule not expanding distolaterally, tapering to broadly rounded distal margin, its distolateral margin moderately curved; ventral face supported by subcentral carina. Ventral costa gently sinuous distally, only slightly inclined distomesially, its terminal part forming truncate blade lying free but against ventral surface of dorsolateral lobule, with distal margin folded dorsally.

Appendix masculina (Fig. 4D) roughly ovate, with proximal part curving ventrally, embracing appendix interna; its distal margin with short setae, mesial margin bearing slender, more numerous setae, and distolateral margin armed with 5 spinules. Appendix interna triangular, distinctly shorter than appendix masculina.

Uropod (Fig. 1) with exopod overreaching telson by length of distal 2/5, 0.76 times as long as carapace; lateral rib strong, tapering to distal spine, accompanied mesially by deep groove along entire length; blade considerably overreaching distolateral spine. Endopod much shorter than exopod, 0.56 times as long as carapace, with sharp median carina extending almost to posterior margin.

Sixth thoracic sternite (Fig. 4A) armed with acute median spine directed anteroventrally. Median plate of seventh sternite roughly triangular with lateral margins somewhat convex, its apex sharply pointed; ventral surface bearing scattered long, stout setae. Eighth sternite anteriorly with large median tubercle bearing several long, stout setae.

Description of female paratype. - The female paratype is somewhat damaged (the distal part of the rostrum has been lost, and some of the pereopods are missing or broken). In general, the external morphology of it agrees with that of the holotype other than the characters showing sexual dimorphism.

Posterodorsal margin of second abdominal somite lacking median spine normally. Sixth somite 0.42 times as long as carapace and 1.59 times as long as anterior depth. Telson 0.54 times as long as carapace.

Scaphocerite 0.70 times as long as carapace.

Third maxilliped (Figs. 4E, F) with propodus having dorsodistal margin not produced forward, without fringe of setae; dactylus without rows of spines on lateral surface, ventral margin less setose than in male. 
Only left members of first and second pereopods and both of third pair complete. First pereopod with chela 1.44 times as long as carpus; dactylus 1.54 times as long as palm. Second pereopod with carpus 1.03 times as long as merus; chela 1.16 times as long as carpus, with 2 photophores; dactylus 1.44 times as long as palm. Third pereopod with carpus 1.10 times as long as merus; chela 0.99 times as long as carpus; dactylus 1.27 times as long as palm. Fourth pereopod with carpus bearing 37 photophores. Fifth pereopod with carpus 1.32 times as long as merus, with 39 photophores.

Uropod with exopod and endopod 0.70 and 0.52 times as long as carapace.

Thelycum (Fig. 4G) with sixth thoracic sternite bearing blunt median elevation ending anteriorly in acute spine. Median plate of seventh sternite triangular, directed anteroventrally, reaching beyond posterior margin of coxae of third pereopods; ventral surface not conspicuously depressed, anterior part with setae, apex rather blunt. Eighth sternite depressed in anterior 3/4, and anterolateral areas more deeply depressed; episternite (Fig. 4H) appearing as rather thin ridge, extending anterolaterally into space between coxae of fourth and fifth pereopods; anterior excavation visible in ventral view.

Coloration. - Body dark reddish brown in general; abdomen posterior to fourth somite pale or nearly colorless. Cornea of eye dark brown. Membranous part of scaphocerite transparent. Photophores on pereopods appearing as series of dark red spots. Pleopods pale red.

Etymology. - The specific name is a noun in apposition from the Latin, pallidus (pale) and cauda (tail), in reference to the coloration.

Distribution. - Known only from off Miyako, Iwate Prefecture, at depths of 500$700 \mathrm{~m}$.
Remarks. - The poorly folded median lobules of the petasma of the male holotype suggest that it is not fully mature, though the third maxilliped shows a distinct secondary sexual character. The long rostrum overreaching the distal margin of the scaphocerite may also suggest the immaturity of the specimen, since it is known that in almost all genera of the Aristeidae the rostrum of the fully mature male is short and in general does not reach the anterior end of the antennular peduncle.

Relationship. - Crosnier (1978) listed the following eight species as members of the genus Aristeus: A. alcocki Ramadan, 1938, from the Indian Ocean; A. antennatus (Risso, 1816) from the eastern Atlantic including the Mediterranean, and the Indian Ocean; A. antillensis A. Milne Edwards \& Bouvier, 1909, from the western Atlantic; $A$. mabahissae Ramadan, 1938, from the IndoWest Pacific; A. occidentalis Faxon, 1893, from the eastern Pacific off Galapagos Islands; A. semidentatus Bate, 1881, from the Indo-West Pacific; A. varidens Holthuis, 1952, from the eastern Atlantic; and $A$. virilis (Bate, 1881) from the Indo-West Pacific. Macpherson (1984) synonymized Aristeus crosnieri Burukovsky, 1975, with Plesiopenaeus nitidus Barnard, 1947. The distinctly longer chelae than carpi of the first and second pereopods and relatively numerous photophores on the pereopods seem to link the new species to $A$. antennatus and $A$. antillensis. At my request, two males of A. antennatus from the Mediterranean (MNHN Na 38, CL 26.5 and 30.0 $\mathrm{mm}$ ) and three females of $A$. antillensis from Surinam (NSMT-Cr 8856, CL 32.4-37.0 $\mathrm{mm}$ ) were made available for comparison. The differences among the new species and the two known species are summarized in Table 2. The new species is distinguished from both $A$. antennatus and $A$. antillensis by the relatively short dactyli of the first to third pereopods, the relatively long merus of the second pereopod, the absence of photo- 
Table 2. Comparison of the morphological differences among Aristeus pallidicauda new species, $A$. antennatus, and A. antillensis. Abbreviations as in Table 1.

\begin{tabular}{|c|c|c|c|}
\hline & A. pallidicauda & A. antennatus & A. antillensis \\
\hline 2 Per Carpus/Merus & $0.99-1.03$ & $0.85-0.87$ & 0.90 \\
\hline $\begin{array}{l}\text { Dactylus/Palm } \\
1 \text { Per } \\
2 \text { Per } \\
3 \text { Per }\end{array}$ & $\begin{array}{l}1.54-1.83 \\
1.32-1.45 \\
1.27-1.28\end{array}$ & $\begin{array}{l}1.78-1.98^{*} \\
1.64-1.75^{*} \\
1.38-1.52^{*}\end{array}$ & $\begin{array}{l}1.73-1.88 \\
1.73-1.88 \\
1.29-1.48\end{array}$ \\
\hline $\begin{array}{l}\text { No. of photophores } \\
1 \mathrm{Per} \\
2 \mathrm{Per} \\
3 \mathrm{Per} \\
4 \mathrm{Per} \\
5 \mathrm{Per}\end{array}$ & $\begin{array}{l}\text { C13,P5 } \\
\text { C0,P2-3 } \\
\text { C0,P2 } \\
\text { C33-37,P20 } \\
\text { C36-39,P31, D22 }\end{array}$ & $\begin{array}{l}\text { C30-41, P8-11* } \\
\text { C6-12,P5-8* } \\
\text { C3-5,P4-5* } \\
\text { C70-85,P57-60* } \\
\text { C65-117,P73-98 } \\
\text { D42-47* }\end{array}$ & $\begin{array}{l}\text { C12-18, P5-6 } \\
\text { C10,P2-3 } \\
\text { C6-7,P2-3 } \\
\text { C27-33,P- } \\
\text { C44-50,P-,D- }\end{array}$ \\
\hline $\begin{array}{l}\text { Male third maxilliped } \\
\text { Dorsodistal margin } \\
\text { of propodus }\end{array}$ & $\begin{array}{l}\text { distinctly produced } \\
\text { forward }\end{array}$ & slightly produced & - \\
\hline Dactylus & $\begin{array}{l}\text { moderately deep, not } \\
\text { setose dorsally }\end{array}$ & $\begin{array}{l}\text { deep, thickly } \\
\text { setose dorsally }\end{array}$ & - \\
\hline Female episternite & $\begin{array}{l}\text { showing as narrow } \\
\text { ridge; anterior exca- } \\
\text { vation visible in ven- } \\
\text { tral view }\end{array}$ & $\begin{array}{l}\text { showing as broad } \\
\text { subtriangular plate; } \\
\text { anterior excavation } \\
\text { hardly visible from } \\
\text { ventral view* }\end{array}$ & $\begin{array}{l}\text { showing as stout eleva- } \\
\text { tion somewhat twisted } \\
\text { posteriorly; anterior } \\
\text { excavation visible in } \\
\text { ventral view } \dagger\end{array}$ \\
\hline
\end{tabular}

*Crosnier (1978); † Crosnier \& Forest (1973)

phores from the carpi of the second and third pereopods, and the shape of the female episternite. Dr. Crosnier suggested to me that the proportion of the pereopodal articles and the number of the pereopodal photophores in species of Aristeus may vary among zoogeographically separated populations. However, he believed that the ranges of variation seem not be sufficiently large to preclude these characters from having a good diagnostic value. The shape of the distal two articles of the third maxilliped seems to separate Aristeus pallidicauda from $A$. antennatus (Fig. 5). However, the consistency of this character in the new species remains questionable due to the immaturity of the holotype.

\section{Aristeus virilis (Bate, 1881)}

Restricted synonymy:

Hemipenaeus virilis Bate, 1881: 187.

Aristaeus virilis: Kubo, 1949: 194, figs. 1B, 6A, 8Y, 11B, 13C, D, 14F, 19A, 23E; 36G, $\mathrm{J}$, 44D, 65A, B, 69D-G, 72B, H, 78E, 85, 86.

Aristeus virilis: Kubo, 1965: 596, fig. 898. - Crosnier, 1978: 61, figs. 25a, b, 26a, b. - Miyake, 1982: 1, pl. 1, fig. 2. - Hayashi, 1983a: 190, figs. 48a, b, 51a-e, 52c, d. - Crosnier, 1984: 21. - Hayashi, 1986: 52 (fig. 13), 53, 237; 1992: 19, figs. 10, 12, $13 \mathrm{c}, \mathrm{d}$.

Material examined. - HUMZ-C 3, 1 female (CL $41.2 \mathrm{~mm}$ ), off Miyako, 400-500 m, 3 Apr. 1987, Danish seine.

Coloration. - Body red entirely; photo- 
phores on pereopods appearing as dark red spots.

Distribution. - The previous records suggest that $A$. virilis is widely distributed in the Indo-West Pacific in depths ranging from 65 to $850 \mathrm{~m}$. In Japanese waters, this species has been recorded from southward to Suruga Bay (Hayashi, 1986), but Toriyama (1986) listed it from the Pacific area off the northeast coast of Honshu mainland.

Remarks. - The female specimen examined is damaged, and agrees with the description given by Kubo (1949). Crosnier (1978) noted minor but distinct differences in the counts of the pereopodal photophores between the Japanese material reported by Kubo (1949) and that from Madagascar, which may be due to variations of populations.

\section{Genus Plesiopenaeus Bate, 1881 Plesiopenaeus edwardsianus} (Johnson, 1867)

Restricted synonymy:

Penaeus edwardsianus Johnson, 1867: 897. Plesiopenaeus edwardsianus: Crosnier, 1978: 88, figs. 31a-c, 32a-c, 33a. - Toriyama \& Hayashi, 1982: 87. - Hayashi, 1983c: 368, figs. 58e-g, 59; 1986: 54 (fig. 15), 55, 238. - Pérez Farfante, 1988: 7, fig. 8. - Hayashi, 1992: 35, figs. 19, 20e-g.

Material examined.-HUMZ-C 4, 1 female (CL $46.1 \mathrm{~mm}$ ), off Miyako, 500-600 m, 27 Mar. 1985, Danish seine. HUMZ-C 2058, 1 female (CL $35.0 \mathrm{~mm}$ ), off Sioya-zaki, Fukushima Prefecture, $37^{\circ} 09^{\prime} \mathrm{N}, 141^{\circ} 41^{\prime} \mathrm{E}$, 375-400 m, muddy bottom, bottom temperature 1.5 C, Nov. 1992, otter trawl (R/V Syunyo-Maru).

Coloration. - Body scarlet entirely; cornea of eye dark brown.

Distribution. - Widely distributed in tropical and warm temperate regions of the Atlantic (northward to New Foundland) and Indo-West Pacific, at depths of 300$1800 \mathrm{~m}$. From Japanese waters, this species has been reported only from Tosa Bay (Toriyama \& Hayashi, 1982; Hayashi, 1983c, 1986, 1992). The present specimens extend the northern limit of the distribution of this species in the western Pacific.

\section{Acknowledgments}

I express my gratitude to Dr. A. Crosnier of the Muséum national d'Histoire naturelle, Paris, for arranging the loan of two male specimens of Aristeus antennatus, and for his invaluable advice and suggestions on the manuscript; Dr. I. Pérez Farfante of the National Museum of Natural History, Smithsonian Institution, Prof. K. Baba of Kumamoto University, and an anonymous reviewer, for their valuable criticisms and suggestions. The hospitality of Dr. M. Takeda during my stay at the National Science Museum, Tokyo, is gratefully acknowledged. Prof. K.- I. Hayashi of Shimonoseki University of Fisheries kindly provided me with important literature.

\section{Literature Cited}

Barnard, K. H., 1947. Descriptions of new species of South African decapod Crustacea, with notes on synonymy and new records. Annals and Magazine of Natural History, series 11, 13: 361 -392 .

Bate, C.S., 1881. On the Penaeidea. Annals and Magazine of Natural History, series 5, 8: 169196, pls. 11, 12 .

Burukovsky, R. N., 1975. Aristeus crosnieri sp. n. (Decapoda, Aristeinae) iz jugo-vostochnoi atlantiki. [Aristeus crosnieri sp. n. (Decapoda, Aristeinae) from the south-east Atlantic]. Zoologicheskii Zhurnal, 54 (5): 779-781.

Crosnier, A., 1978. Crustacés Décapodes, Pénéides Aristeidae (Benthesicyminae, Aristeinae, Solenocerinae). Faune de Madagascar, 46: 1197.

_, 1984 . Penaeoid shrimps (Benthesicymidae, Aristeidae, Solenoceridae, Sicyonidae) collected in Indonesia during the Corindon II and IV Expeditions. Marine Research in Indonesia, 24: $19-47$.

_ _ \& Forest, J., 1973. Les crevettes profondes de l'Atlantique oriental tropical. Faune Tropicale, 19: 1-409.

Duvernoy, G. L., 1840. Sur une nouvelle forme de 
branchies, découverte dans une espèce de Crustacé décapode macroure qui devra former le type d'une genre nouveau (Aristeus antennatus Nob.). Annales des sciences naturelles, serie 2, Zoologie, 15: 218-220. (not seen)

Faxon, W., 1893. Preliminary descriptions of new species of Crustacea. Reports on the dredging operations off the west coast of Central America to the Galapagos, to the west coast of Mexico, and in the Gulf of California, in charge of Alexander Agassiz, carried on by the U. S. fish commission steamer "Albatross" during 1891. VI. Bulletin of the Museum of Comparative Zoology at Harvard College, 24: $149-220$

Hayashi, K.-I., 1983a. Prawns, shrimps, and lobsters from Japan (11). Family Aristeidae (Aristeinae) - genus Aristeus. Aquabiology, 5 (3): 188-191. (in Japanese).

- 1983b. Prawns, shrimps, and lobsters from Japan (12). Family Aristeidae (Aristeinae) genera Aristaeomorpha and Hepomadus. Aquabiology, 5 (4): 280-283. (in Japanese).

, 1983c. Prawns, shrimps, and lobsters from Japan (13). Family Aristeidae (Aristeinae) genera Hemipenaeus and Plesiopenaeus. Aquabiology, 5 (5): 366-369. (in Japanese).

_ 1986. Penaeidea and Caridea. In: Baba, K., Hayashi, K.-I., \& Toriyama, M., Decapod Crustaceans from Continental Shelf and Slope around Japan: 38-149, 232-279. Japan Fisheries Resource Conservation Association, Tokyo. (in Japanese and English)

- 1992. Dendrobranchiate Crustacea from Japanese Waters. Seibutsu Kenkyusha, Tokyo, ix +300 pp.

Holthuis, L. B., 1952. Crustacés Décapodes Macrures. Résultats scientifiques, Expedition océanographique belge dans les Eaux côtières africaines de l'Atlantic sud (1948-1949), 3 (2): $1-88$.

Johnson, J. Y., 1867. Description of a new genus and a new species of macruran decapod Crustacea belonging to the Penaeidae, discovered at Madeira. Proceedings of the Zoological Society of London, 1867: 895-901.

Komai, T., 1991. Deep-sea decapod crustaceans from the Pacific coast of eastern Hokkaido, northern Japan (Crustacea, Decapoda, Penaeidea and Caridea). Report of North Japan Sub-committee for Bottom Fish, Research Committee for Fishery Resources, 24: 55-96.

Kubo, I., 1949. Studies on penaeids of Japanese and its adjacent waters. Journal of the Tokyo College of Fisheries, 36: 1-467.

- 1965. Crustacea, Decapoda, Macrura. In: Okada, Y. K., Uchida, S., \& Uchida, T., (eds.), New Illustrated Encyclopedia of the Fauna of Japan, 2: 591-629. Hokuryukan, Tokyo. (in Japanese)

Macpherson, E., 1984. Crustáces Decápodos del Banco Valdivia (Atlántico sudoriental). Resultados Expediciones Científicas del Buque
Oceanográfico Cornide de Saavedra, 12: 39105.

Milne Edwards, A. \& Bouvier, E. L., 1909. Les Pénéides et Sténopides. Reports on the results of dredging under the supervision of Alexander Agassiz in the Gulf of Mexico (1877-78), in the Caribbean Sea (1878-79) and along the Atlantic coast of the United States (1880) by the U.S. coast survey steamer "Blake", Lieut.Com. C. D. Sigsbee, U. S. N., and commander J. R. Bartlett, U. S. N., commanding. Memoirs of the Museum of Comparative Zoology at Harvard College, 27 (3): 177-274, pls. 1-9.

Miyake, S., 1982. Japanese Crustacean Decapods and Stomatopods in Color. Vol. I. Macrura, Anomura, and Stomatopoda. Hoikusha, Osaka, iii + 261 pp., 56 pls.

Pérez Farfante, I., 1977. American solenocerid shrimps of the genera Hymenopenaeus, Halipoloides, Pleoticus, Hadropenaeus new genus, and Mesopenaeus new genus. Fishery Bulletin, 75 (2): 261-346.

- , 1987. Revision of the gamba prawn of the genus Pseudaristeus, with description of two new species (Crustacea: Decapoda: Penaeoidea). Fishery Bulletin, 85 (2): 311-338.

-, 1988 . Illustrated key to penaeoid shrimps of commerce in the Americas. NOAA Technical Report, NMFS, 64: i-iv, 1-32.

Ramadan, M. M., 1938. Crustacea: Penaeidae. Scientific Report of John Murray Expedition, 1933-34, 5 (3): 35-76.

Risso, A., 1816. Histoire naturelle des Crustacés des environs de Nice: 1-175, pls. 1-3. (not seen)

- 1827. Histoire naturelle des principales productions de l'Europe méridionale et particulièrement de celles des environs de Nice et des Alpes-Maritimes, 5: I-VIII, 1-403, pls. 110. (not seen)

Toriyama, M., 1986. Outline of the research. In: Baba, K., Hayashi, K.-I., \& Toriyama, M., Decapod Crustaceans from Continental Shelf and Slope around Japan: 18-29. Japan Fisheries Resource Conservation Association, Tokyo. (in Japanese and English) , \& Hayashi, K.-I., 1982. Fauna and distribution of pelagic and benthic shrimps and lobsters in the Tosa Bay exclusive of rocky zone. Bulletin of the Nansei Regional Fisheries Research Laboratory, 14: 83-105.

Wood-Mason, J., 1891. On the results of deep-sea dredging during the season 1890-1891. Crustacea. Natural history notes from H. M. Indian Marine Survey Steamer "Investigator," Commander R. F. Hoskyn, R. N., commanding. Annals and Magazine of Natural History, series 6, 8: 269-286.

Department of Animal Sciences, Natural History Museum and Institute, Chiba, 955-2 Aoba-cho, Chuo-ku, Chiba 260, Japan. 